\title{
Is appendectomy always the adequate treatment? Clinical manifestations of isolated actinomycosis in appendix
}

\author{
Veysi Hakan Yardimci ${ }^{1}$ (D), Aytul Hande Yardimci² (D) \\ 1 Faculty of Health Sciences, İstanbul Gelisim University, İstanbul, Turkey \\ ${ }^{2}$ Clinic of Radiology, University of Health Sciences, İstanbul Basaksehir Cam and Sakura City Hospital, İstanbul, Turkey
}

\begin{abstract}
Isolated appendiceal actinomycosis is a rare chronic progressive suppurative infection. Causative agent in humans is gram-positive saprophytic anaerobic bacteria, Actinomyces Israelii. Herein, it was aimed to present a case of acute appendicitis that developed in a 54-year-old female due to isolated appendiceal actinomycosis. Diagnosis of appendiceal actinomycosis causing acute appendicitis is generally performed postoperatively histopathologically, and appendectomy alone is not sufficient in treatment. It is an important point that should be considered by clinicians that definitive treatment of the infection is possible by appropriate antibiotic use.
\end{abstract}

Keywords: Appendicitis, actinomycosis, laparoscopic appendectomy, actinomyces

Cite this article as: Yardimci VH, Yardimci AH. Is appendectomy always the adequate treatment? Clinical manifestations of isolated actinomycosis in appendix. Turk J Surg 2021; 37 (4): 403-407.

\section{Corresponding Author}

Veysi Hakan Yardımcı

E-mail: hakanyardimci@yahoo.com

Received: 01.11.2017

Accepted: 02.01.2018

Available Online Date: 31.12 .202

o Copyright 2021 by Turkish Surgical Society Available online at www.turkjsurg.com

DOI: $10.47717 /$ turkjsurg.2021.4015

\section{INTRODUCTION}

Acute appendicitis, with its $7.6 \%$ incidence in society (8.6\% for males and $6.7 \%$ for females) is the most commonly seen gastrointestinal surgical pathology necessitating emergency surgery (1). Acute appendicitis develops by the obstruction of the appendiceal lumen. Increased luminal pressure and impaired circulation causes bacterial propagation and increased mucus and induces inflammatory response of the physiopathological process. The most frequent causes of obstruction are lymphoid hyperplasia, fecaloid, foreign materials, tumors and parasites. Appendiceal actinomycosis is one of the rare causes of acute appendicitis.

Real acute actinomyces infection of the appendix can only be differentiated from ileocecal actinomycosis by actinomyces granules that are detected in the appendiceal lumen (2). Real acute actinomyces infection of the appendix is extremely rare (2). Accurate diagnosis in these cases is clinically important since insufficient treatment may result in risks of long-lasting disease, frequently seen local dissemination and metastatic abscess. On the other hand, chronic suppurative appendicitis is the clinical form that develops subsequent to acute clinical picture (2).

Herein, it was aimed to present a case of acute phlegmonous appendicitis caused by localized actinomyces infection alone.

\section{CASE REPORT}

A 54-year-old female patient presented to our hospital with a two-day history of complaining of right lower abdominal pain, nausea and vomiting. Her medical history was unremarkable. Physical examination of her abdomen revealed rebound tenderness over the lower-right abdominal quadrant, no mass was palpable. There was a mild fever $37.9^{\circ} \mathrm{C}$. Laboratory findings were normal, except for white blood cell count (WBC) 14500/ $\mathrm{mm}^{3}$ and C-reactive protein level of $6.5 \mathrm{mg} / \mathrm{L}$. Abdominal tomography without contrast enhancement revealed an enlarged proximal segment of the appendix $(11 \mathrm{~mm})$ and an increased wall thickness. Hyperdense material was detected compatible with appendicolith in the lumen. CT findings were compatible with acute appendicitis (Figure 1). Surgery was planned with the 

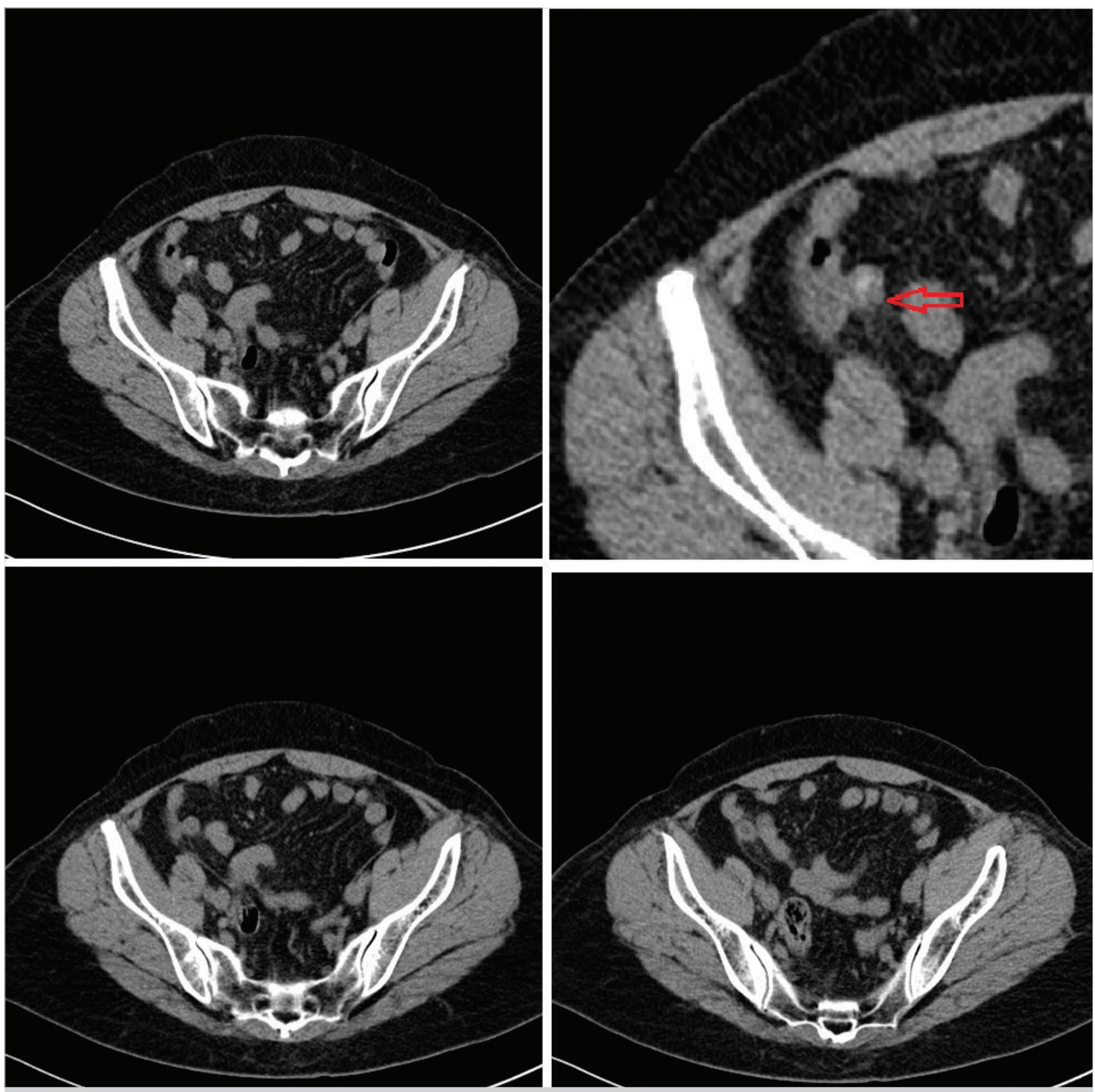

Figure 1. Abdominal CT images: An enlarged proximal segment of appendix (11 mm.), increased wall thickness, hyperdense material compatible with appendicolith in the lumen.

suspect of acute appendicitis. Laparoscopic appendectomy was performed. The vermiform appendix $45 \mathrm{~mm} \times 12 \mathrm{~mm}$ was found. Although serosal layer of the appendix and mesoappendix were surrounded by fibrotic tissue, exploration of the ileocecal region was normal (Figure 2). The patient recovered well postoperatively and was discharged from hospital on postoperative day 1. The diagnosis of actinomycosis of the appendix was established histologically. Microscopic examination revealed acute phlegmonous appendicitis and actinomyces sulfur granules scattered in the purulent exudate in the appendiceal lumen (H\&E x 2). Microscopic x10 magnification revealed typical sulfur granule in lesion (H\&E x 10) (Figure 3). Colonies of actinomyces were seen intramurally and intraluminally with Grocott's stain and PAS stain (Figure 4). After definitive diagnosis of appendiceal actinomycosis, the patient was readmitted to the hospital and treated with high doses penicillin G IV for two weeks. Then amoxicillin (oral $2 \mathrm{gm} /$ day for six months) was pre- 


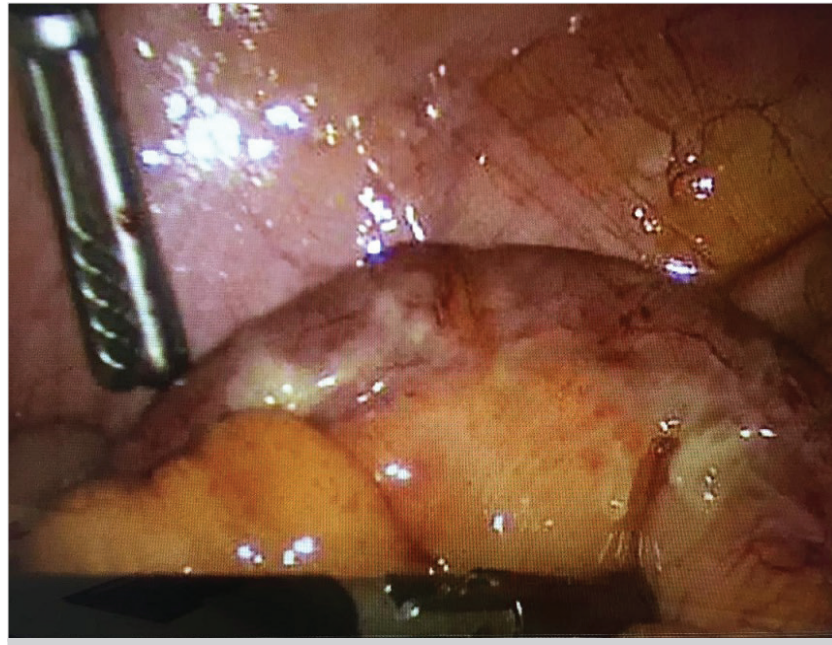

Figure 2. Laparoscopic view: Serosal layer of appendix and mesoappendix were surrounded by fibrotic tissue.
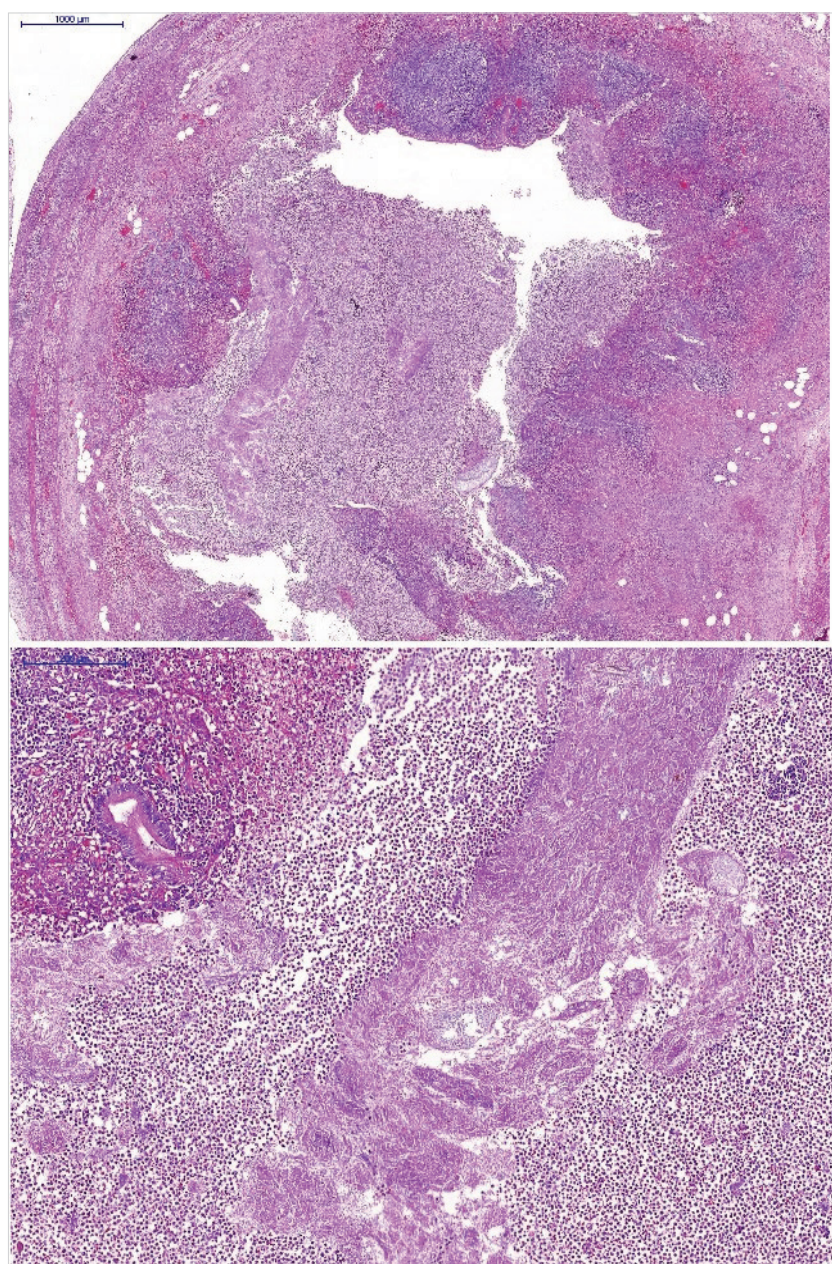

Figure 3. Diagnosis of actinomycosis was established with the presence of sulphur granules microscopically. Acute phlegmonous appendicitis. Actinomyces sulfur granules scattered in the purulent exudate in the appendiceal lumen (H\&E x 2). Actinomyces sulfur granules (H\&E x 10). scribed for completing the treatment. Five years have passed and no clinical recurrence is mentioned.

A signed written informed consent was obtained from the patient who participated in this case.

\section{DISCUSSION}

Actinomycosis is subacute-chronic bacterial infection affecting soft tissues and internal organs of the body. The most common pathogen that causes actinomycosis in humans is Actinomyces Israelii $(3,4)$. This micro-organism can be frequently found in normal human mouth flora, and less commonly in lower gastrointestinal tract and female genital tract as well (4). Although Actinomyces Israelii is a non-pathogenic bacterium, mucosal injuries that cause disruption of the mucosal barrier allow the microorganisms to reach deep planes, resulting in actinomycosis infections in the human. The infection leads to formation of granuloma and abscess, followed by consequent healing of sinuses and drained fistulae. Involvement of distant organs is possible via hematogenous metastasis at any stage of the disease (2). The disease may spread via venous route, leading to formation of metastatic abscesses in the liver. Actinomycosis cases among humans are seen in three forms; namely the cervicofacial form, which is the most frequent form observed in 50-70\% of cases, and less frequently, the thoracic and abdominopelvic forms observed in $15-20 \%$ and $10-20 \%$ of cases, respectively (3).

The disease is often seen in populations with low socio-economic level, and in individuals with bad oral hygiene aged between 20-50 years. Actinomycosis infection is more prevalent among men, with a male:female ratio of $3: 1$, whereas the pelvic form is more frequent among women (3). The cause is often the prolonged use of intrauterine contraceptive devices (IUCD), which causes chronic injury that allows bacteria to penetrate the mucosal barrier and reach deep tissues $(5,6)$. Abdominal form of the disease is typically associated with history of previous abdominal surgery. Pathologies that disrupt the integrity of the gastrointestinal mucosa, such as perforated appendicitis, perforated diverticulitis, endoscopic procedures, trauma, Crohn's disease, and intestinal perforation due to ingestion of bone or fishbone are predisposing factors that play role in the etiology (7).

Other known predisposing systemic factors include immunosuppression, malnutrition, and AIDS. Our case did not have any known local or systemic predisposing factor such as history of previous abdominal surgery.

Abdominopelvic actinomycosis can be clinically manifested with fistula, sinus, inflammatory pseudotumor or abscess, and it can often mimic other diseases clinically. The affected organ is surrounded by dense fibrous tissue, and the disease can mimic malignant diseases due to this mass appearance (3). Isolated actinomycosis of the appendix has non-specific clinical, laborato- 

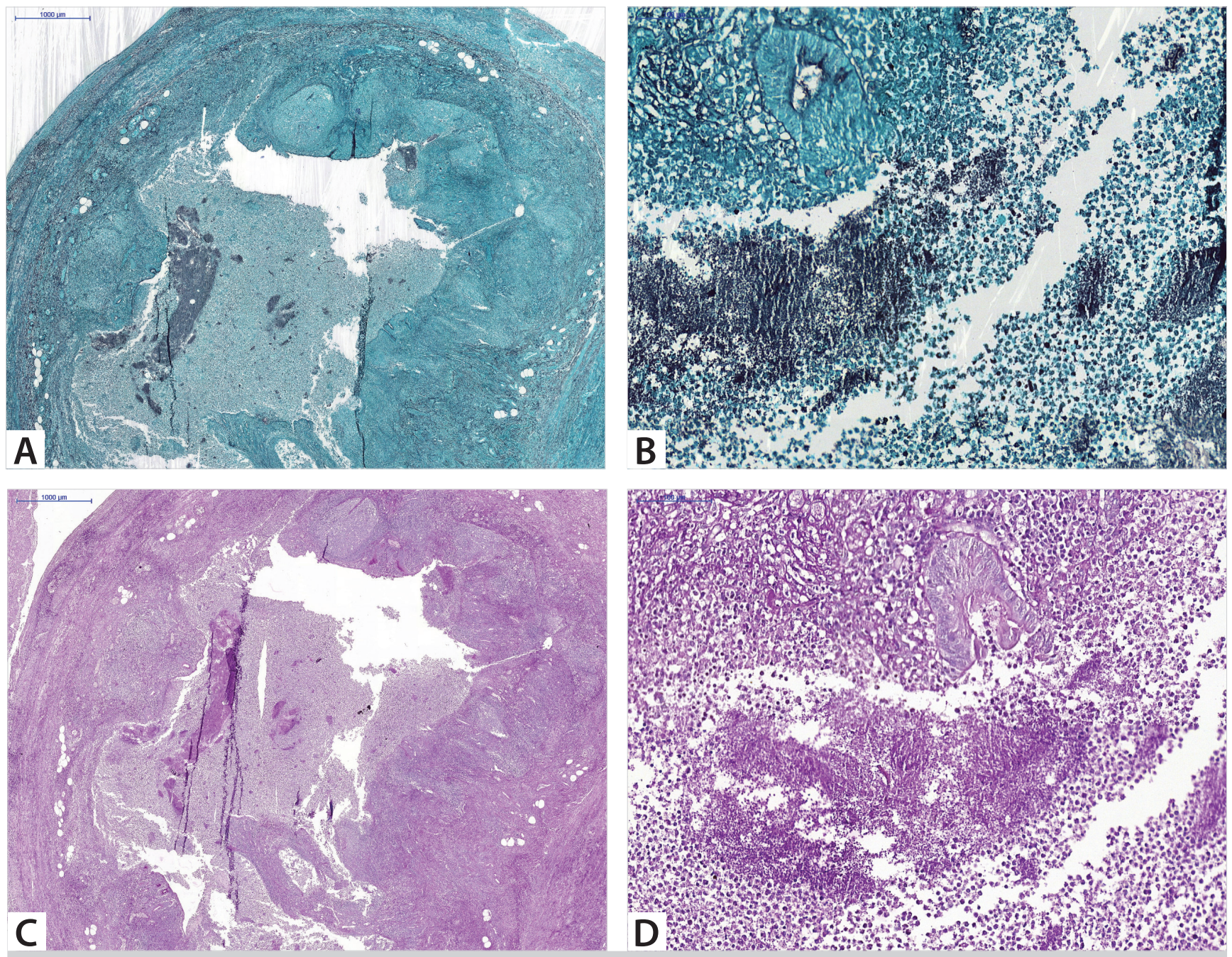

Figure 4. Colonies of actinomyces (stained black with Grocott's stain) were seen intramurally and intraluminally. A. Actinomyces sulfur granules positive with Grocott methenamine silver stain (x2). B. Grocott methenamine silver stain (x20). C. Actinomyces sulfur granules positive with PAS stain (x2). D. PAS stain (x20).

ry and radiological findings, and therefore, the disease mimicking acute appendicitis is usually very hard and often impossible to diagnose preoperatively (8). Radiological investigations are often nondiagnostic especially when there is no mass lesion or abscess concurrent with the diagnosis of acute appendicitis as in our case.

According to the literature, the diagnosis of abdominal actinomycosis could be made preoperatively in only $10 \%$ of the cases $(6,8,9)$. Upon suspicion of the disease, the diagnosis can be made with microscopical examination of the fine-needle aspiration material. However, the diagnosis is often made with intraoperative or post-operative histopathological examination. Histologically, the microorganism forms actinomycotic granules (sulphur granules) (10). These are made of irregular round bacterial aggregations surrounded by eosinophilic material, and they are typical for the disease. In our case, the diagnosis was possible by observation of the typical sulphur granules detected during histopathological examination.

Studies report over $90 \%$ success rate in treatment of abdominal actinomycosis infections when treated with a combination of antibiotics and surgical resection (6). Preferred antibiotic treatment includes high dose crystalline penicillin G (2-4 weeks) and consequent long-term (6-12 months) oral penicillin or semi-synthetic penicillin derivatives $(6,7)$.

\section{CONCLUSION}

Appendiceal actinomycosis is a rare pathology that should be considered by clinicians among the causes of acute appendicitis. Accurate diagnosis is the key to treatment success. Control and cure of the infection is only possible with long-term penicillin treatment after appendectomy. 
Peer-review: Externally peer-reviewed.

Author Contributions: Concept - V.H.Y., A.H.Y.; Design - V.H.Y., A.H.Y.; Supervision - V.H.Y., A.H.Y.; Materials - V.H.Y., A.H.Y.; Data Collection and/or Processing - V.H.Y., A.H.Y.; Literature Search - V.H.Y., A.H.Y.; Writing Manuscript - V.H.Y., A.H.Y.; Critical Reviews - V.H.Y., A.H.Y.

Conflict of Interest: The authors have no conflicts of interest to declare.

Financial Disclosure: The authors declared that this study has received no financial support.

\section{REFERENCES}

1. Kavic SM. Laparoscopic appendectomy. Wetter PA (ed). Prevention and Management of Laparoendoscopic Surgical Complications. $3^{\text {th }}$ ed. Florida: Society of Laparoendoscopic Surgeons; 2010. pp. 239-48. [CrossRef]

2. Day DW, Jass JR, Price AB, Shepherd NA, Sloan JM, Talbot NJ, et al, (eds). Morson and Dawson's gastrointestinal pathology. $4^{\text {th }} \mathrm{ed}$. New Jersey: Blackwell Science; 2003. [CrossRef]

3. Triantopoulou C, Van der Molen A, Van Es A, Giannila M. Abdominopelvic actinomycosis: spectrum of imaging findings and common mimickers. Acta Radiol Short Rep 2014; 3(2): 1-5. [CrossRef]
4. Karakuş E, Mambet E, Azılı MN, Gülhan B, Tiryaki T, Tezer H. Actinomycosis of the appendix in childhood-an unusual cause of appendicitis. APSP J Case Rep 2014; 5(3): 26. [CrossRef]

5. Radha P, Condon AF, Yong Kuei TL. Case report of pelvic actinomycosis presenting as a complex pelvic mass. J Preg Child Health 2015; 2(1): 125. [CrossRef]

6. Castro LL, Cabral MMDA, Andrade RFM, Buzatti KCLR, Silva RG. Actinomycosis mimicking colonic neoplasia. J Coloproctol 2012; 32(3): 312-5. [CrossRef]

7. Maternini M, Saucy F, Sandmeier D, Vuilleumier H. Simple appendicitis? Can J Surg 2008; 51(3): E54-55. [CrossRef]

8. Bittencourt JA, Andreis EL, Lima EL, Dorn DE, Muller V. Actinomycosis simulating malignant large bowel obstruction. Braz J Infect Dis 2004; 8(2): 186-9. [CrossRef]

9. Sumer Y, YIlmaz B, Emre B, Ugur C. Abdominal mass secondary to actinomyces infection: An unusual presentation and its treatment. J Postgrad Med 2004; 50(2): 115-7. [CrossRef]

10. Paritsky $M$, Cherepnin L. Abdominal actinomycosis mimicking chronic appendicitis. J Clin Case Rep 2012; 2: 14. [CrossRef]

\section{OLGU SUNUMU-ÖZET}

Turk J Surg 2021; 37 (4): 403-407

\section{Apendektomi her zaman yeterli tedavi midir? İzole apendiks aktinomikozunun klinik bulguları}

Veysi Hakan Yardimci ${ }^{1}$, Aytul Hande Yardimci ${ }^{2}$

${ }^{1}$ İstanbul Gelişim Üniversitesi, Sağlık Bilimleri Fakültesi, İstanbul, Türkiye

${ }^{2}$ Sağlık Bilimleri Üniversitesi, İstanbul Çam ve Sakura Şehir Hastanesi, Radyoloji Kliniği, İstanbul, Türkiye

\section{ÖZET}

İzole Apendiks aktinomikozu seyrek rastlanan kronik progresif süpüratif bir enfeksiyondur. İnsanda etken gram-pozitif saprofitik anaerobik bakteri olan Actinomyces Israelii'dir. Bu makalede biz 54 yaşında kadın hastada izole apendiks aktinomikozuna bağlı gelişen akut apandisit vakasını sunuyoruz. Akut apandisite neden olan apendiks aktinomikozu tanısı genellikle ameliyat sonrası histopatolojik olarak konulabilmekte ve tedavide yanlız apendektomi yeterli olmamaktadır. Enfeksiyonun kesin tedavisi için uzun süreli, uygun antibiyotik kullanımı klinisyenlerin hatırında tutması gereken bir noktadır.

Anahtar Kelimeler: Apandisit, aktinomikoz, laparoskopik apendektomi, aktinomiçes

Doi: $10.47717 /$ turkjsurg.2021.4015 